\title{
The Symphony Of Southeast Texas In 2010: Managing A Regional Orchestra In Modern Times
}

Craig Escamilla, Lamar University, USA

Enrique (Henry) R. Venta, Lamar University, USA

\begin{abstract}
The Symphony of Southeast Texas is a regional, professional symphony orchestra based in Beaumont, TX. The orchestra operates on an annual budget of approximately $\$ 550,000$, and employs musicians on a per-service basis. In 2009, the orchestra hired a new Music Director following two years of searching and auditions. Chelsea Tipton, II, ignited a fire amongst all of the organizations constituents from his first visit to Beaumont for his audition in March 2009. Following his appointment as Music Director, the organization's members realized what a remarkable opportunity was at hand for the orchestra. The organization had to capitalize on the enthusiasm surrounding a new Music Director, but this came with a unique set of challenges. Orchestras, like non-profit organizations in general, struggle with maintaining a sustainable business model. This case study describes the opportunities, and the challenges associated with them, that regional orchestras, and similarly positioned small non-profit organizations, face.
\end{abstract}

Keywords: not for profit; management, marketing; services; orchestras; Board of Directors

\section{INTRODUCTION}

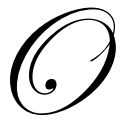

n October 17, 2009, Chelsea Tipton, II, debuted as the new Music Director of the Symphony of Southeast Texas. With a record classical concert audience of over 1,000 attendees, number of tickets sold totaling almost 1,250, and media coverage generating an electric buzz in the community, the orchestra was moving forward into a new era. The success of the first concert, and the energy generated by it, presented previously unknown opportunities for the orchestra to achieve new successes. However, as with all nonprofit organizations, the Symphony of Southeast Texas was facing its share of challenges. The orchestra, coming off of an $80 \%$ turnover in staff, faced the opportunity for significant changes to allow greater growth into the future. With the selection of a new leader for the orchestra, one who could be present, active, and involved in the friendly and intimate community of Beaumont, Texas, the orchestra's Board and staff prepared for the best. However, constituents quickly realized that the growth and success of the organization could not depend only upon the new Music Director. Everyone had a responsibility to step up to the plate, and help guide the future of the organization. The orchestra's leadership began assessing all operations and found the following results.

\section{OVERVIEW}

\section{Mission}

The mission of The Symphony of Southeast Texas is to develop, maintain, and nurture a symphony orchestra of the highest achievable artistic quality that will, within a viable economic framework, play a major role in the education, entertainment and cultural enrichment of all residents of Southeast Texas. 


\section{History \& Programs}

The Symphony of Southeast Texas, based in Beaumont, is the area's only professional symphony orchestra. It is also the only professional orchestra between Houston, TX, and Lake Charles, LA. Four classical concerts and one symphony pops concert currently comprise the orchestra's subscription season. Additionally, the orchestra performs four free youth education concerts for area students, a free July 4 concert in conjunction with the City of Beaumont's festivities, and an occasional "run-out" concert in nearby towns. With the exception of "run-outs", all performances are at the Julie Rogers Theatre in Beaumont, and the season typically runs from October to April. The orchestra plans its concerts and guest artists approximately one year in advance, but often reserves concert dates two to three years in advance.

\section{MUSIC DIRECTOR SEARCH}

\section{7-2008 Search}

In 2006, the Symphony of Southeast Texas announced that its Music Director/Conductor would be leaving at the conclusion of the 2006-2007 season. During his tenure, the quality of the orchestral playing improved dramatically, a goal of the search committee that selected him in 2001. This improvement, however, came with a price: the replacement of many, long standing, Beaumont based orchestra members with "imported" players from Houston. The maestro's relationship with the orchestra's Board and patrons can also be characterized as tense, but respectful. His goal was to broaden the audience's and orchestra's horizons, often through a combination of hard work and challenging, and sometimes unfamiliar, repertoire.

With the announcement of the maestro's departure, the Board of Directors commenced with a search for a new Music Director. A thirteen-member committee, made of Board members, Symphony League members, and musicians, was assembled to drive the search process. Four candidates were selected, from nearly 150 applicants, to "audition" during the 2007-2008 season. The "audition" would consist of a variety of Board, Symphony League, and committee meetings, as well as the standard series of four rehearsals and one performance to conclude the week. The selection process began with the organization's previous Executive Director accepting and reviewing the initial pool of 130 applicants. With some help from two search committee members, the pool was cut approximately in half. The remaining candidates' resumes were presented to the Search Committee members for review. Each member ranked the candidates based solely on their resume. The rankings were combined, and the pool was narrowed to approximately twelve. The twelve remaining candidates submitted conducting videos, which were reviewed by the committee. Committee members also contacted references for these candidates. After reducing the number of candidates to five, the committee conducted telephone interviews, and selected the four finalists.

During the 2007-2008 season, the first candidate withdrew her name from consideration. While the three remaining candidates had their share of strengths, good ideas, and creativity, none of them felt like the perfect fit for the orchestra. Faced with the crucial, make or break decision of selecting the best new Music Director, the search committee opted to continue the search, with new candidates, during the 2008-2009 season.

The reaction to the decision to continue the search was quite harsh. Orchestra and audience members felt that their voice was not heard during the process. Several longstanding donors and supporters considered withdrawing their sponsorships. Advance season ticket sales declined from 2007-2008 to 2008-2009. However, the search committee remained confident that its decision would prove itself correct. With only four months to accept applications, and narrow the pool of nearly one hundred applicants to four candidates, the search committee worked diligently during the summer of 2008.

\section{8-2009 Search}

Prior to reviewing any applications, the Search Committee members participated in a paired weighting exercise to determine the most desired characteristics in the new Music Director (See Exhibit I). The committee suggested fifteen potential characteristics for rating to determine those most desired in the new Music Director. Committee members compared each alternative choosing the one of the two that was most important to him/her. 
Each member then totaled the number of times he/she chose each number ( 1 through 15$)$. The total for each number for each committee member was combined to create a master rating. The numbers were then ordered beginning with the one that had been chosen the greatest number of times by the group. The list of characteristics, and the number of votes each received, is shown below.

1. Sincerity/Authenticity (55)

2. Conducting Skills (54)

3. $\quad$ Programming ability based on Symphony of Southeast Texas' needs (49)

4. Musicianship (48)

5. Ability to teach/develop the orchestra (47)

6. Commitment (43)

7. $\quad$ MD experience (34) tied with Collegiality (34)

8. Charisma (33)

9. Education Concert conducting experience (28) tied with Marketing experience (28)

10. Asst. Conductor experience (27)

11. Fundraising experience (25)

12. National exposure (23)

13. Youthfulness (8)

The committee members agreed that the first six characteristics were indeed the most important to them. They also noted the significant drop in number of votes from item 6 to item 7. This drop indicates that after item 6 , the remaining characteristics are not as important to the committee members. The committee was able to use this list as a basis for comparing the four finalists in the 2008-2009 season. The members were able to compare the candidates to the list, and to one another. The committee felt strongly that this exercise helped focus the group, and eventually led to the successful conclusion of the search.

Additionally, to narrow down the initial pool of nearly 100 new applicants, the committee hired Henry Fogel, President of the League of American Orchestras, to serve as a consultant. Mr. Fogel provided feedback about each of the applicants in an effort to assist the committee members in narrowing the pool to qualified candidates who might be a good fit for the Symphony of Southeast Texas. Mr. Fogel cautioned the committee members not to make the process too quantitative, but rather to "trust their gut" and look for the "right fit".

Four candidates were selected, and accepted the invitation to audition for the job. The orchestra's constituents were much more satisfied with the potential of one of the candidates from the 2008-2009 season to be the orchestra's next leader. At the conclusion of the season, with nearly unanimous orchestra, Board, and audience support, the orchestra hired Chelsea Tipton, II, as its new Music Director.

What set Maestro Tipton apart? One staff member notes, "I like Chelsea because he is such a genuine, 'down-to-earth' guy. He is forthright, honest, and just a nice guy, and I'm looking forward to working with him." A Board member commented on the Maestro's selection, "I'm glad the committee picked the one I wanted!" As Maestro Tipton prepared for his first season, he expressed a desire to focus on improving consistency of the orchestra personnel. It was his feeling that this consistency would lead to improved quality of playing, familiarity amongst the orchestra with his conducting style, and familiarity for the audience with the faces on stage. He also expressed a genuine interest in getting involved in the community, and making an impact in area school districts to emphasize the orchestra's role in local music education.

As the orchestra prepared for the 2009-2010 season, the Southeast Texas community was abuzz with excitement about the orchestra's new Music Director. The response was fitting considering that the short, opening work on his audition concert in March 2009 received a standing ovation at its conclusion. The enthusiasm following that concert was contagious, and the orchestra was thrilled with the opportunities that the new Maestro's appointment provided. 


\title{
ORGANIZATIONAL STRUCTURE
}

\section{Staff}

A music director, an executive director, a director of operations, and an administrative assistant/bookkeeper comprise the orchestra's full time staff. The orchestra does not have a marketing director, or a development director.

The Music Director's responsibilities include conducting all of the orchestra's concerts and rehearsals, being the "face" of the orchestra to the community, working closely with the personnel manager on orchestra personnel issues, working with the librarian on musical repertoire issues, working with the Executive Director and the Board of Directors on programming and fundraising activities, and promoting the orchestra throughout the community.

\begin{abstract}
The Executive Director is responsible for the oversight of all of the orchestra's operations, with primary focuses on human resource management, financial oversight, operations oversight, and fundraising/development/grant writing activities. Other responsibilities, primarily due to the small nature of the organization's staff, include writing/distributing press releases for performances, designing each concert's program book and the orchestra's bi-monthly newsletter, and similar tasks. Duties assumed by the Administrative Assistant include ticket sales management, database management, accounting and bookkeeping, and general administrative duties. The director of operations is responsible for assembling the necessary group of musicians for each performance, finding substitutes to fill temporary vacancies and/or musician absences, working with the Julie Rogers Theatre staff to ensure that the stage is set properly for each rehearsal and performance, and renting/distributing musical selections to the orchestra members prior to each concert.
\end{abstract}

The orchestra's financial resources prevent the offering of significant employee benefits. Benefits are limited to a minimal monthly health insurance reimbursement. Employees are expected to find their own insurance coverage toward which the aforementioned reimbursement may be applied.

\section{Orchestra Musicians}

The Symphony of Southeast Texas employs approximately 60 musicians for each performance. The musicians are paid per service. Services consist of rehearsals and performances. Each classical concert has four rehearsals and one performance, while the other concerts each have only one rehearsal. The typical four-rehearsal schedule involves Tuesday, Wednesday, and Thursday evening rehearsals with a dress rehearsal the afternoon of the concert day. The typical one rehearsal schedule involves a rehearsal the evening prior to the concert for daytime concerts or a rehearsal during the day for an evening concert. It is essential to have four full rehearsals for classical concerts because those rehearsals are the only time the orchestra works on the repertoire for that specific concert. Since the musicians do not play together on a weekly basis, four rehearsals are crucial for developing group cohesiveness and preparing the concert.

Although some musicians are members of the American Federation of Musicians, they are not under any type of collective bargaining agreement with the orchestra. A lack of string players in the Southeast Texas area necessitates supplementing local musicians with players from Houston. These supplementary players are often students or freelance musicians. A Board member says of the orchestra's makeup, "It's discouraging to know that there are talented musicians in this area, quite capable of playing in our orchestra, who are not doing so." This quote summarizes the sentiment of many of the orchestra's patrons. However, another Board member says of the orchestra members, "If quality is compromised to ensure that there are more local players in the orchestra, I'm less likely to attend. I want to attend a good, high quality concert; otherwise, I can simply go to a Houston Symphony concert."

The orchestra's new Music Director, Chelsea Tipton, II, has mentioned many times that his biggest goal in his first season is to increase the consistency of orchestra personnel from one performance to the next. His next goal is to focus on improving the quality of the performances. In his opinion the two go hand in hand. As the orchestra began its strategic planning process in late 2009, musician representation in Board activities increased significantly, for the first time in recent history, with the inclusion of two musicians on the planning committee. The orchestra's 
management and Board members were surprised to hear the musician representatives' ideas about the organization overall, and that their ideas were not colored by complaints or personal agendas. Additionally, some of the best ideas during a roundtable discussion of what the orchestra does well and what it could do better came from the two musicians. The experience emphasized the value of good communication between constituents.

\section{Board of Directors}

The Board of Directors of the Symphony of Southeast Texas has 70 members, each elected to a 3-year term. Members' terms can be renewed an unlimited number of times, as long as the organization wishes to renew their term and they are willing to continue serving. 49 Board members and 3 Symphony League members are voting directors, while the remaining 21 are mostly honorary and advisory members. The by-laws indicate that the number of voting members cannot exceed 75 , but cannot be less than 30 . Local business owners/leaders, community figures, and educational leaders are members of the Board. Each member is asked to purchase season tickets, attend concerts regularly, contribute (or help raise) at least $\$ 1,000$ each season, and attend Board and committee meetings regularly. However, only slightly more than $50 \%$ of the Board members fulfill any one of these opportunities to support the orchestra.

A 13-member executive committee leads the Board of Directors. (See Exhibit II) Each officer serves a oneyear term. A seven member nominating committee makes officer and new Board member recommendations. The membership votes on the recommendations at the annual meeting of the organization. Honorary and advisory members are not obligated to the commitments of regular, voting members. Honorary membership has gradually become easier to achieve because of a lack of argument on the part of the nominating committee when someone asks to become an honorary member. The by-laws, however, indicate that the Executive Committee shall recommend honorary members for their extensive contributions of time, services, or money to the orchestra. Additionally, honorary members who have moved away from the area, and have little or no active involvement in the orchestra's activities anymore, continue to be maintained as honorary members.

The Symphony of Southeast Texas Board of Directors is charged with the ultimate responsibility for the health and success of the organization. The chain of command for the orchestra can be seen as a pyramid with the Board President and Executive Committee at the top. The Executive Director and Music Director are equal employees at the second level, with the musicians under the Music Director, and the administrative staff under the Executive Director. The Board falls somewhere in between under the Executive Committee's supervision. The Board is made up of volunteers; no members are paid. This is important because technically a volunteer is in charge of the organization's activities.

Despite the large size of the Board, average attendance at Board meetings is about 35 directors. Board committees usually consist of 6-8 directors, although average attendance at committee meetings is about 3-4 directors. The orchestra faces the challenge of motivating a large and busy group of people around its cause. Potential director conflicts of interest, most of which relative to the Symphony of Southeast Texas are non-financial, must also be avoided. To do so, the orchestra implements a series of checks and balances, the most important of which is a thorough conflict of interest policy. Finally, the orchestra must identify and develop new leaders to carry the organization forward to greater successes.

One Board member notes, "I am curious to know if the orchestra plans to implement a process for identifying and developing new talent and leadership on the Board." Most of the Board members are older, wealthier, and well-established members of the community. Board members typically have little direct involvement in the daily operations of the organization, leaving these operations to the staff hired by the organization. This can, however, create problems when questions about operations arise because of the lack of direct, hands on experience on the Board's end. There is, perhaps, a tendency amongst Board members to reflect on the past, especially those who have been involved with the orchestra for many years. Comments from Board members often begin with "We used to..." or "Why don't we... anymore?" When new ideas are introduced, a frequent response is "We tried that once before, but it didn't work." 
One Board member commented to the new Music Director, "Motivating the Board of Directors is very difficult. There are a lot of people, good people, involved with the orchestra, but some of them seem to be here only to list their involvement on their resume." Another Board member admitted "it frustrates me when Board members and musicians ask why we didn't avoid this or that conflict with $\mathrm{x}$ community event. We have to plan our concerts years in advance, and can't constantly shift dates to avoid every possible conflict. There will always be something else going on, but it's the Board's job to advocate for the Symphony, and make it the primary event that people desire to attend." A member of the Executive Committee comments, "I don't think, as just a general member of the Board, I ever realized just how much work the small staff of the Symphony of Southeast Texas does. The resources are extremely limited, yet an enormous amount of extremely high quality work always gets done." Overall, the Board is very supportive of the organization, and is active in promoting the orchestra throughout the community. Motivation and communication are important tasks for the staff and Board to share. One Board member notes that the orchestra should make it a priority to focus more on "internal marketing" to its various constituencies.

\section{Symphony League of Beaumont}

The Symphony League of Beaumont supports the orchestra through various fundraising activities and contributions. The Symphony League has over four hundred members. More often than not, though, the same small group of volunteers can be found doing the majority of the work. Both organizations have a responsibility to motivate members to get more involved in the activities of both organizations. The orchestra is sitting on a goldmine of potential audience members. However, there is a perception that some of these potential audience members may not even realize that there is a connection between the Symphony of Southeast Texas and the Symphony League.

The organization holds two annual gala events to raise money for the orchestra, in addition to numerous smaller educational and cultural activities throughout the year. The organization focuses on cultural education and appreciation by middle and high school students in the area. The Symphony League is a separate organization from the orchestra, and is deeply involved in its various activities, most of which add great value to the community. Interaction between Symphony League members and the orchestra's staff, Board, and musicians, is limited. Although representatives of both organizations sit on each other's Boards, interaction is often limited to meetingoriented interactions.

\section{FINANCIAL OVERVIEW}

The Symphony of Southeast Texas is a 501(c)(3) non-profit organization. The organization's income comes in two forms: earned and contributed. Earned income is derived from ticket and program ad sales. As indicated by EXHIBIT III, earned income comprises slightly more than $20 \%$ of all income. Contributed income, derived from individual and corporate sponsorships, grants, and contributions from the Symphony League, and endowment income, comprise the remainder of the orchestra's income. This heavy reliance on contributed income is a concern for the orchestra's Board and staff. There are many reasons that may cause a donor to reduce, or eliminate entirely, his/her contribution to the orchestra. This uncertainty makes the budgeting process quite difficult. The current donor system is a tiered system featuring 8 different donor categories (based on amount contributed) and a permanent endowment category. Various benefits are available for donors at each level with the magnitude of the benefit increasing as the contribution increases.

Over the past few years, the orchestra's leaders have been extremely conservative when budgeting income, but extremely liberal when budgeting expenses. Artistic expenses make up slightly more than $50 \%$ of the operating budget. The administration considers this a reasonable and accurate percentage, since these funds are expended directly on performances, which are the main purpose of the organization's existence. Production and administrative expenses comprise the rest of the expense side of the budget. The goal of the Symphony of Southeast Texas is to keep administrative overhead expenses low, while using the majority of the organization's funds for its core activities. If a surplus exists at the year's end, it is expected that the excess funds will be reinvested into new projects and activities.

Where many for-profit organizations have numerous forms of controllable revenue, the Symphony's controlled streams are limited. Therefore, the question of how to increase ticket sales and attendance is crucial to the 
long-term survival of the organization. With a heavy dependence on contributed income, the Symphony of Southeast Texas derives its support from audience members' desire to be involved with the organization. Developing sympathy for the cause is an important responsibility for the Symphony of Southeast Texas. The orchestra wonders how it can break this cycle of uncontrollable dependence in order to free up more funding for expanding its program offerings. Leadership questions how to expand the audience, and whether to expand laterally, or to attempt to reach new audience segments. Ultimately, though, the goal is to figure out how to make each concert a must see event.

\section{AUDIENCE INVOLVEMENT}

The Julie Rogers Theatre, where the Symphony of Southeast Texas performs, seats 1,663 audience members. Average ticket sales for a Symphony of Southeast Texas concert, including those audience members who purchased season tickets, number approximately 1,200. However, actual concert attendance ranges from 700-800 people per performance. It is rare that a person who purchases a single ticket to a specific concert does not actually attend the performance. It is much more frequent for season ticketholders to miss various individual performances throughout the season. The orchestra's administration also questions the nearly 500 -seat difference in sold tickets and available seats, and wonders how to increase demand. Traditionally, the orchestra's annual Pops concert sells many more tickets than the classical concerts, and often the full number of available tickets is sold. However, attendance, though higher at the Pops concert than the classical concerts, still remains low relative to the number of seats sold, with a number of ticket purchasers not using their tickets.

A Symphony of Southeast Texas concert usually lasts about two hours, including social time before and after the concert, and a twenty-minute intermission. This length is consistent with the average length of orchestra concerts across the nation. The orchestra moved its performances from Thursdays at 8:00 p.m. to Saturdays at 7:30 p.m.at the start of the 2004-2005 season. Since the change, a handful of longtime supporters have expressed dissatisfaction with the concerts on Saturdays because of the numerous other local activities that demand their time. Despite this small group's insistence that the change has upset a great number of concertgoers, the Symphony's Board and administration feel strongly that conflicts will both exist, and arise, regardless of the day and time of the performances. The orchestra faces competition from other local activities such as concerts, Broadway touring shows, movies, and high school sports. The latter conflict is predominant in the Southeast Texas area, and, for example, prevents the orchestra from holding any major activities on Friday evenings in the fall to avoid Friday night football.

The Symphony of Southeast Texas has been evaluating its involvement with audience members before, during, and after performances. The orchestra began holding pre-concert discussions during the 2009-2010 season. The discussions provide an opportunity for audience members to dive a bit deeper into the repertoire to be performed that night. They usually take place about 30-45 minutes prior to the performance, in the theatre. The discussions are very common at other orchestras. The orchestra has volunteers on hand at the performance to take ticket stubs and distribute program books, but no one to direct patrons to their seats, or assist in other usher-like ways. Another type of audience engagement is a post-concert discussion during which the conductor, and possibly guest artist, sits on stage following the concert and interact with audience members who choose to stay. The Symphony of Southeast Texas is exploring this concept.

The average audience member's demographic is similar to Board members'. This conforms to the usual standard for orchestras around the country. One Board member notes, "I see more young people beginning to attend our concerts, and I think it's a good thing. I wonder, beyond offering $\$ 5$ student rush tickets, how we can continue to attract younger audience members." A Symphony staff member comments, "I do think it's important to attract younger audience members, however, I can think of at least 100 potential audience members in their 40s or 50s who may not even know there is a Symphony of Southeast Texas. I'm equally interested in finding ways to attract those potential patrons." Finding ways to resume relationships with audience members who have lost contact with the orchestra is an important goal of the Symphony of Southeast Texas.

\section{MARKETING}

Since 2007, the local cable company in Beaumont, TX, has generously agreed to donate three weeks of complimentary advertising, across all 78 channels, for each Symphony of Southeast Texas concert during the 
season. Another generous underwriter sponsored the development and production of the ad spot. The Symphony of Southeast Texas has no other television advertising spots beside the aforementioned donation. These spots run with increasing frequency as the concert approaches, and the average exposure is about one hundred, two hundred, and three hundred spots for weeks three, two, and one away from the concert, respectively. However, with increased use of the Internet, especially by younger potential audience members, the Symphony questions whether television ads, even complimentary ones, are effective means of developing new audiences.

The Symphony of Southeast Texas also receives complimentary radio advertising time on several local stations, but does not receive complimentary production of these ads. This has been a significant deterrent to any major radio campaigns, because production can quickly become very expensive. The orchestra also purchases an ad for each concert, for the week preceding the performance, in the local newspaper. Readership has declined significantly in recent months, though, and the newspaper production's relocation to Houston following Hurricane Ike has reduced the amount of local news and event coverage. Therefore, whereas the orchestra previously depended on a feature article covering the concert, plus the newspaper advertisement, the leadership now sees an ad in a small paper reaching a small readership.

The orchestra distributes a press release prior to each concert it performs. The release reaches local daily and weekly publications, local television, and local radio stations. Often the releases are overlooked, or copied (with severe edits) into the publication with little or no genuine interest or support. Appearances on local morning radio and television shows get a face for the orchestra before the public, but exposure at prime air times and on prime programs, is limited or nonexistent. The Symphony of Southeast Texas tends to receive the most attention for its annual pops concert, when local media outlets lavish extensive attention on the orchestra's upcoming performance. However, the organization's leadership wonders how to bring that same interest and energy to its classical performances.

The orchestra does not participate in Internet advertising, other than its website, designed at the organization's office. The Symphony of Southeast Texas pays for the services of a local advertising agency to assist with the preparation, production, and distribution of ads. However, the company is stretched entirely too thin, and the need for advance exposure before a Symphony concert is often not a priority for the last minute ad design world. The lack of controllable revenue streams prevents the orchestra from allocating significant amounts of money toward advertising.

The Symphony of Southeast Texas, like all orchestras, faces the challenge of differentiating one classical concert from another in press releases. For example, the orchestra may play an overture by Beethoven on its first concert, and a symphony by Beethoven on its second concert. To the average media reporter there may seem to be no difference between the two concerts, when in reality, the Beethoven work on the first concert may be a 10 minute long concert opener, while the Beethoven work on the second concert may be his 35 minute Symphony No. 5, arguably the most famous piece of music ever written. Thus, a lack of clear differentiation may be a detriment to the orchestra's publicity efforts. The orchestra, like most, is probably deficient in this area.

Without a marketing staff member, the orchestra's administration is uncertain about the best publicity vehicles to promote its product. The limited time that the small staff, and the volunteer Board, has to devote to marketing prevents any real focused, planned, and innovative strategies for increasing public exposure. In 20092010, the orchestra plans to heavily promote its new Music Director, but the administration is concerned about interest in him past the first concert of the season.

\section{WHAT IS NEXT?}

The Symphony of Southeast Texas' leadership is determined to find the best way to achieve its goals and to bring its message to a broader constituency of the Southeast Texas area. However, many challenges and roadblocks exist for the orchestra to overcome. A responsibility to aggressively seek, recognize, invest in, and develop local talent and leadership is crucial to the organization's continued success. The new Music Director has a responsibility to be a true community player and advocate for the organization throughout Southeast Texas. A need to aggressively monitor the Symphony's financial situation and to not only maintain stability, but to seek new funding opportunities, 
is also essential to the orchestra's continued success. Finally, a need to reach out to new groups, via new and unique means, is a component that will ensure genuine interest and involvement for years to come. With 56 years behind the organization, the groundwork must be laid now to ensure at least 56 more years of success. The orchestra's leadership agrees that stability and status quo are not enough - that only growth, expansion, and new horizons will suffice. In an effort to grow and expand, the leadership is enthusiastic about finding new ways to achieve greatness for the Symphony of Southeast Texas.

\section{AUTHOR INFORMATION}

Craig Escamilla has served as Executive Director of the Symphony of Southeast Texas in Beaumont since August 2007. In this capacity, he has led the orchestra through two seasons of a Music Director search, and has overseen the financial stability of the organization's $\$ 500,000$ plus budget. In addition to his duties at the Symphony, Craig serves as an adjunct instructor of management at Lamar University, Beaumont. A native of Beaumont, TX, he is a graduate of Lamar University, Beaumont, with the Master of Business Administration and the Bachelor of Music degrees.

Enrique (Henry) R. Venta serves as Dean of the College of Business and Professor of Management at Lamar University. His teaching and research activities are in the areas of strategic issues in operations and managing the service sector. He holds Ph.D. and M.S. degrees from Northwestern University and a B.S. I. E. degree from the University of Puerto Rico. He has published more than 40 articles, chapters and monographs and currently on the Texas Emerging Technology Fund Advisory Committee as well as on the board of several civic and service organizations. 


\section{EXHIBIT I}

\section{Pair Weighting Exercise}

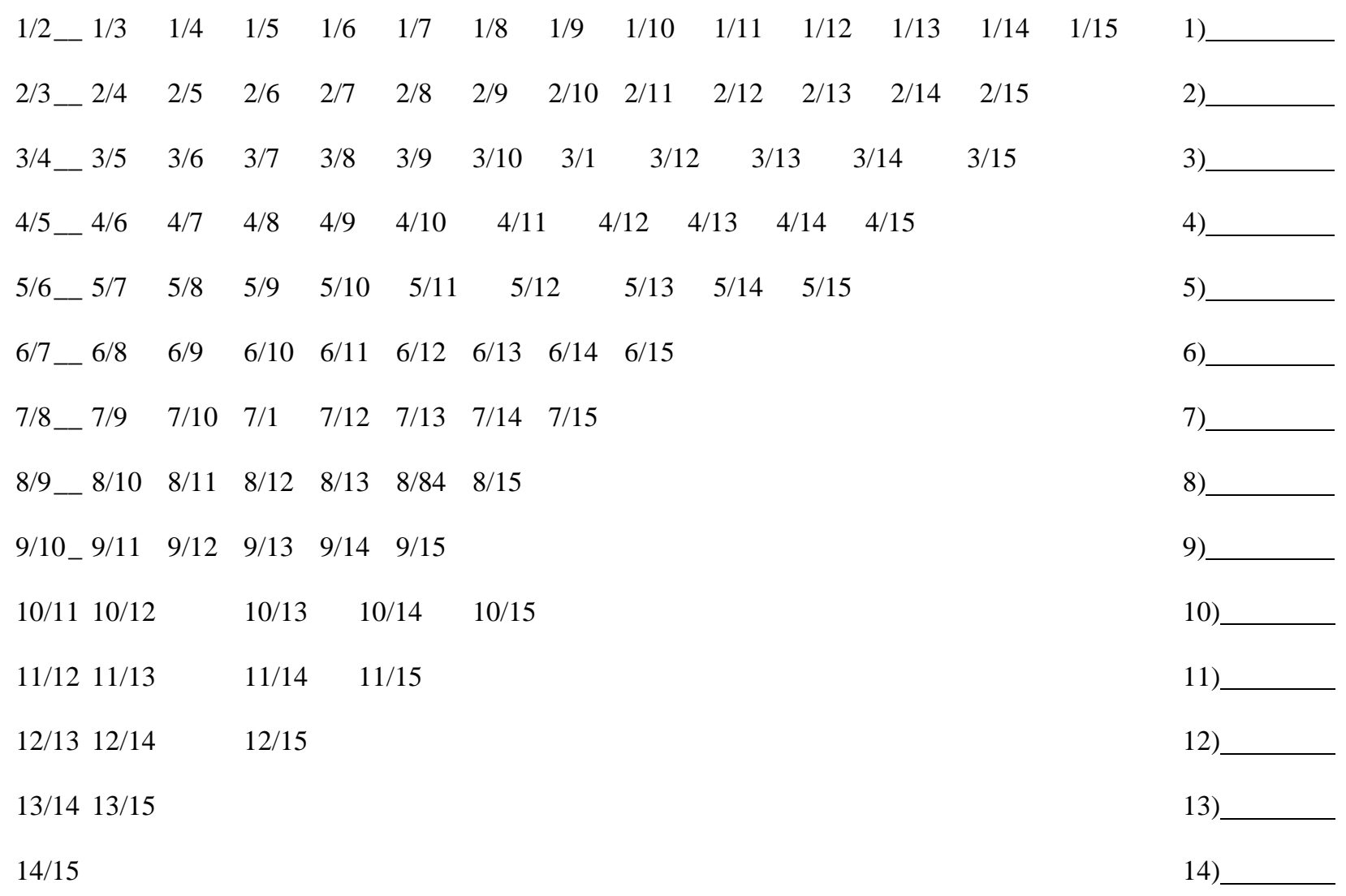

\section{EXHIBIT II}

\section{Symphony of Southeast Texas Executive Committee Positions}

President

President-Elect

VP-Corporate Development

VP-Individual Development

VP-Administration

VP-Education

VP-Marketing

VP-Audience Development

Treasurer

Secretary

Past President

Symphony League President

Local University Music Dept. Chair 


\section{EXHIBIT III}

\section{Symphony Financials}

\begin{tabular}{|c|c|c|c|c|c|}
\hline $\begin{array}{l}\text { INCOME } \\
\text { TICKET SALES }\end{array}$ & $\begin{array}{c}2009 \\
\text { YTD } \\
\text { ACTUAL } \\
99,580 \\
\end{array}$ & $\%$ & $\begin{array}{c}\begin{array}{c}2008 \\
\text { YTD } \\
\text { ACTUAL }\end{array} \\
117,742 \\
\end{array}$ & $\%$ & $\begin{array}{c}\begin{array}{c}2007 \\
\text { YTD }\end{array} \\
\text { ACTUAL } \\
92,468 \\
\end{array}$ \\
\hline DEVELOPMENT & 175,258 & $\%$ & 186,312 & 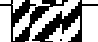 & 187,763 \\
\hline TEMPORARILY RESTRICTED INCOME & & 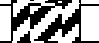 & 21,906 & 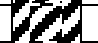 & 34,097 \\
\hline EDUCATION & 22,000 & $\%$ & 20,000 & $\%$ & 21,500 \\
\hline SYMPHONY LEAGUE & 63,000 & $\%$ & 70,000 & 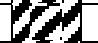 & 84,500 \\
\hline INTEREST/DIVIDENDS & 19,793 & 1 & 23,124 & O & 21,526 \\
\hline MAPES & & & 99,532 & $\%$ & 99,045 \\
\hline ADVERTISING & 26,800 & $\%$ & 21,325 & 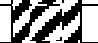 & 16,880 \\
\hline PERFORMANCE FEES & & $\%$ & 10,258 & $\%$ & 7,937 \\
\hline MISCELLANEOUS & & $\%$ & 333 & $\%$ & 6,439 \\
\hline TOTAL INCOME & 406,431 & & 570,532 & $1 \%$ & 572,155 \\
\hline $\begin{array}{l}\text { EXPENSE } \\
\text { ARTISTIC SALARIES }\end{array}$ & 45,804 & & 43,688 & & 85,891 \\
\hline SYMPHONY CHORUS & & & 2,560 & $\%$ & \\
\hline ORCHESTRA MUSICIANS & 151,424 & $\%$ & 159,112 & $\%$ & 139,402 \\
\hline GUEST ARTISTS & 39,065 & & 46,058 & $\%$ & 40,754 \\
\hline PRODUCTION EXPENSE & 36,262 & 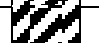 & 33,014 & & 25,912 \\
\hline PROGRAM BOOK EXPENSE & 16,993 & $\%$ & 16,621 & $1 \%$ & 17,375 \\
\hline MARKETING & 11,204 & $\%$ & 16,022 & & 30,436 \\
\hline EDUCATIONAL EXPENSE & 17,255 & $\%$ & 20,380 & & 36,779 \\
\hline STAFF SALARIES & 84,941 & $\%$ & 75,063 & 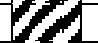 & 111,900 \\
\hline OFFICE EXPENSE & 32,218 & $\%$ & 32,652 & $\%$ & 37,433 \\
\hline MILEAGE, PARKING, MEALS & 1,235 & $\%$ & 1,073 & & 492 \\
\hline $\begin{array}{l}\text { PROFESSIONAL DEVELOPMENT } \\
\end{array}$ & 2,142 & $\%$ & 6,443 & $\%$ & 178 \\
\hline DUES \& SUBSCRIPTIONS & 2,078 & 1 & 2,541 & $\%$ & 2,306 \\
\hline LIABILITY/WORKERS COMP INSURANCE & 7,807 & $\%$ & 4,405 & & 10,044 \\
\hline AUDIT & 4,750 & & 4,350 & & 3,745 \\
\hline BANK CHARGES & 8,564 & 1 & 9,087 & & 7,722 \\
\hline DEVELOPMENT & 859 & & 563 & $\%$ & 2,272 \\
\hline DEPRECIATION & & & 2,070 & 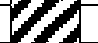 & 3,431 \\
\hline MISCELLANEOUS & 714 & 1 & 331 & & 2,085 \\
\hline BOARD MEETING & 893 & & 1,018 & & 966 \\
\hline \multicolumn{6}{|l|}{ STRATEGIC PLANNING } \\
\hline \multicolumn{6}{|l|}{ REIMBURSEMENT ACCOUNT } \\
\hline DEBT SERVICE & 217 & & 2,992 & & 6,646 \\
\hline TOTAL EXPENSES & 464,425 & & 480,043 & & 565,769 \\
\hline NET INCOME/(LOSS) & $(57,994)$ & $m$ & 90,489 & \# & 6,386 \\
\hline \multicolumn{6}{|l|}{ ENDOWMENT FUNDS } \\
\hline \multicolumn{6}{|l|}{ BMC Guest Artist Endowment } \\
\hline BMC Education Endowment & 75 & & & & \\
\hline JOHN QUIGLEY ENDOWMENT & 1,400 & & 700 & & 350 \\
\hline CARLUCCI ENDOWMENT & 550 & & 286 & & 200 \\
\hline \multicolumn{6}{|l|}{ DOYLE PENMANSHIP AWARD } \\
\hline NET GAINS/LOSSES ON INVESTMENTS & $(107,842)$ & & $(24,561)$ & & 56,325 \\
\hline \multirow{2}{*}{$\begin{array}{l}\text { TOTAL } \\
\text { NET INCOME/(LOSS) w/ENDOWMENT FUNDS }\end{array}$} & $(105,817)$ & 10 & $(23,575)$ & C & 56,875 \\
\hline & $\overline{(163,811)}$ & ZZ & 66,914 & WC & 63,261 \\
\hline
\end{tabular}


Journal of Business Case Studies - November/December 2010

Volume 6, Number 6

NOTES 